\title{
Microbes and the Dissipation of Energy and Respiration: From Cells to Ecosystems
}

\author{
BY CRAIG A. CARLSON, PAUL A. DEL GIORGIO, AND GERHARD J. HERNDL
}

In the year 1974, Larry Pomeroy first proposed that microbes were true movers of energy and nutrients in marine food webs (Pomeroy, 1974). This idea was later formalized as the "microbial loop" (Azam et al., 1983; Pomeroy et al., this issue) in which energy and carbon lost from the planktonic food web in the form of dissolved organic matter (DOM) was recovered and repackaged by heterotrophic bacterioplankton to particulate organic matter (POM). Their ecological role within the microbial loop is to facilitate the transformation of DOM to POM (a trophic "link") (Azam et al., 1983) or to remineralize DOM back to its inor- chemistry is elucidated in studies of how the flow of energy through microbial processes manifests itself as demand for and recycling of elemental nutrients.

Prokaryotes (bacteria and archaea) are now recognized as the most abundant living component of the biosphere with approximately $12 \times 10^{28}$ cells found in the oceanic water column (Whitman et al., 1998). This prokaryotic biomass is comprised of vast phylogenetic diversity (Venter et al., 2004; Giovannoni and Stingl, 2005; Moran et al., this issue; Edwards and Dinsdale, this issue, Breitbart et al., this issue) as well as metabolic diversity (King, 2005; DeLong

\section{Prokaryotes (bacteria and archaea) are now recognized as the most abundant living component of the biosphere...}

ganic constituents (a respiratory "sink") (Ducklow et al., 1986). These early studies laid the conceptual framework for investigations that linked microbial processes to the flow of energy in marine food webs (microbial ecology or trophodynamics). The link to ocean biogeo- et al., 2006). Although prokaryotic processes and trophic interactions occur on the spatial scale of nanometers (Azam, 1998), their sheer numbers and the rates at which they operate have major biogeochemical implications on the scale of ecosystems.
In the contemporary aerobic ocean, the metabolic strategy for the vast majority of prokaryotes is chemoheterotrophy. Heterotrophic bacterioplankton are the major respirers (Sherr and Sherr, 1996; Rivkin and Legendre, 2001), with organic compounds serving as both the electron donors as well as carbon sources, and oxygen functioning as electron acceptor. As organic matter is catabolized, both organic matter and $\mathrm{O}_{2}$ are consumed, resulting in anabolism (biosynthesis) and $\mathrm{CO}_{2}$ production. In terms of energy and carbon cycling within the ocean, it is these chemoorganotrophic organisms that are the most important physiological group. They are instrumental in the transformation of organic matter, its remineralization to inorganic constituents (Ducklow et al.,

CRAIG A. CARLSON (Carlson@lifesci.ucsb. edu) is Associate Professor, Marine Science Institute, University of California, Santa Barbara, CA, USA. PAUL A. DEL GIORGIO is Associate Professor, Département des Sciences Biologiques, Université du Quebec à Montreal, Canada. GERHARD J. HERNDL is Department Head, Biological Oceanography, Royal Netherlands Institute for Sea Research (Royal NIOZ), Texel, The Netherlands. 
1986), and shaping of the organic and inorganic environment (Williams and del Giorgio, 2005). These organisms and their associated processes will be the focus of this article.

One of the fundamental properties that determines bacterioplankton's ecological or biogeochemical role in the marine ecosystem is the amount of biomass produced per unit of organic $\mathrm{C}$ consumed, or the bacterial growth efficiency (BGE) (Sherr and Sherr, 1996; del Giorgio and Cole, 1998). BGE is a measure of the coupling between catabolic (energy-yielding) reactions to anabolic (biosynthetic; energyrequiring) reactions and is expressed by the formula,

$\mathrm{BGE}=\mathrm{BP} /(\mathrm{BP}+\mathrm{BR})$

where $\mathrm{BP}$ is bacterial production and BR is bacterial respiration. Here we will examine how microbial energetics of heterotrophic bacteria partition energy and carbon on a cellular level (Figure 1), how that partitioning affects their growth efficiency, and how that growth efficiency affects their ecological and biochemical roles in the sea.

\section{CELLULAR BIOENERGETICS}

The first law of thermodynamics states that the total amount of energy in the universe is conserved and cannot be created nor destroyed. As a result, all organisms have evolved physiological strategies to conserve energy by collecting, converting, and storing that energy principally via the synthesis of adenosine-5'-triphosphate (ATP). Energy is harvested from light (phototrophy), the oxidation of inorganic compounds (chemolithotrophy) (see Kolber

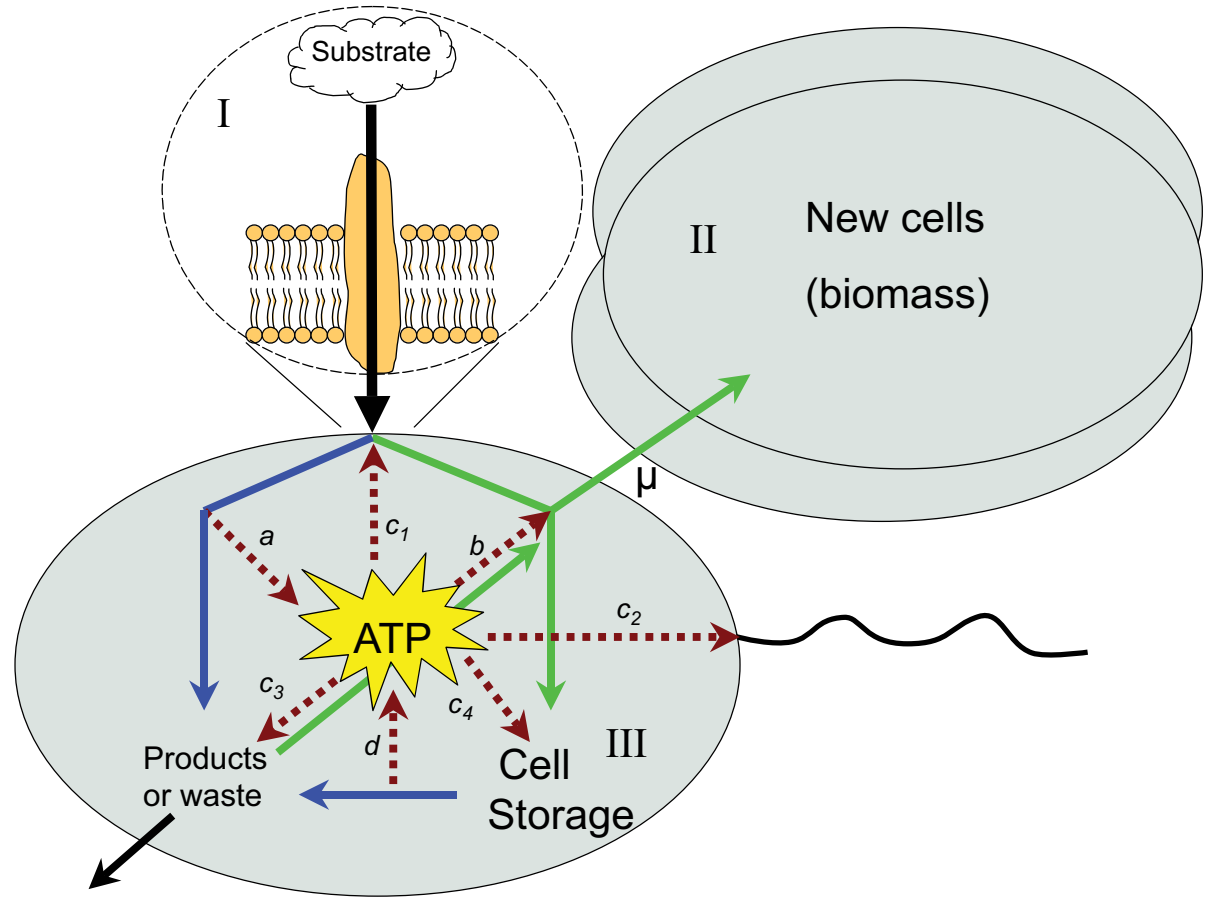

Figure 1. Substrate and energy flow within a cell. Substrate $<700 \mathrm{Da}$ are actively taken up via membrane proteins (I). As the substrate enters the cell via active uptake, it either enters into catabolic pathways (blue lines) or anabolic pathways (green lines). Monomers for anabolism can come preformed from the environment or as products of catabolism. The red-hashed lines represent the flow of energy to and from these metabolic pathways. Energy is conserved via substrate catabolism and ATP is produced at a rate $a$. As ATP is hydrolyzed, energy is released and utilized at rate $b$ to drive anabolic processes such as production of new cells (growth; II) and production cell storage products (III). Energy is also utilized at various rates to support processes that are independent of anabolism. This maintenance energy is used at rates $c_{1}$ to activate uptake systems, $c_{2}$ to fuel cell motility, $c_{3}$ to actively eliminate waste, and $c_{4}$ to repair cellular machinery. In the absence of exogenous organic substrates, the cell can yield ATP at rate $d$ by catabolizing storage material (endogenous substrates). Adapted from del Giorgio and Cole (1998)

et al., this issue, for details on these two metabolic strategies), or the oxidation of organic compounds (chemoorganotrophy). ATP is synthesized via one of three distinct mechanisms: substrate-level phosphorylation (fermentation), photophosphorylation, or oxidative phosphorylation (respiration). Except for obligate fermenters, all microbes carry out respiration. On the cellular level, respiration is the key process of energy conservation in which an electrochemical potential is generated from the flow of electrons from reduced compounds through a membrane transport system to an electron acceptor. The generated chemical energy is used to drive the cells' metabolic processes (Jones, 1983).

The second law of thermodynamics states that in all processes or reactions, some of the energy involved irreversibly loses its ability to do work as a system moves from order to disorder (entropy). From the standpoint of energy flow within a cell, the hydrolysis of ATP transfers the energy conserved from catabolic reactions to energy-requiring reactions that support anabolism (Figure 1). 
However, cells expend energy in ways that are independent of cell biomass production via processes such as overflow metabolism, futile cycles, and maintenance metabolism (see Russell and Cook, 1995) (Figure 1). Thus, efficiency of energy use with regard to biomass production (growth efficiency) can vary significantly depending on the physicalchemical state of the environment.

\section{Overflow Metabolism}

Laboratory cultures of bacteria grown in energy and substrate-rich media often display an uncoupling of catabolism from anabolism, resulting in nongrowth energy dissipation rather than maintenance energy expenditure (see Teixeira-de-Mattos and Neijssel, 1997; Liu, 1998, and citations therein). Under this scenario, energy generated from catabolism is in excess of that needed for anabolism; thus, the cell wastes ATP via extracellular release of DOM. It is not known to what extent energy dissipation via overflow metabolism occurs in natural systems, but several studies have demonstrated production of recalcitrant DOM in cultures of natural assemblages of bacterioplankton (Brophy and Carlson, 1989; Heissenberger and Herndl, 1994; Ogawa et al., 2001; Kawasaki and Benner, 2006). Little is known about why free-living bacterioplankton would actively release DOM extracellularly in substrate-limited systems like the open ocean. It has been shown that highly metabolically active bacterioplankton are engulfed by a polysaccharide envelope (Heissenberger et al., 1996) (Figure 2) in which a major part of the cell's ectoenzymes is embedded (Martinez and Azam, 1993). This polysaccharide capsule might act as sorption/scavenging site for organic molecules for subsequent cleavage by ectoenzymes and is constantly renewed (Stoderegger and Herndl, 1998). Hence, heterotrophic microbial processes might be important sources of recalcitrant DOM (Tanoue et al., 1995; McCarthy et al., 1998). The pool of recalcitrant or semi-labile DOM is biologically reactive. However, its production and subsequent remineralization are uncoupled for time scales of months to decades resulting in accumulation (Carlson, 2002).
Maintenance Metabolism

A more ecologically important mechanism in natural systems is the free energy allocated to nongrowth reactions. Known as maintenance energy, it serves to keep entropy low by fixing what breaks within the cell; thus, it helps a cell to maintain its molecular, cellular, and functional integrity (Hoehler, 2004). The larger the partitioning of energy into maintenance processes, the lower the energetic efficiency of the cell. Studies of bacterial growth in pure bacterial cultures demonstrate that rates of catabo-
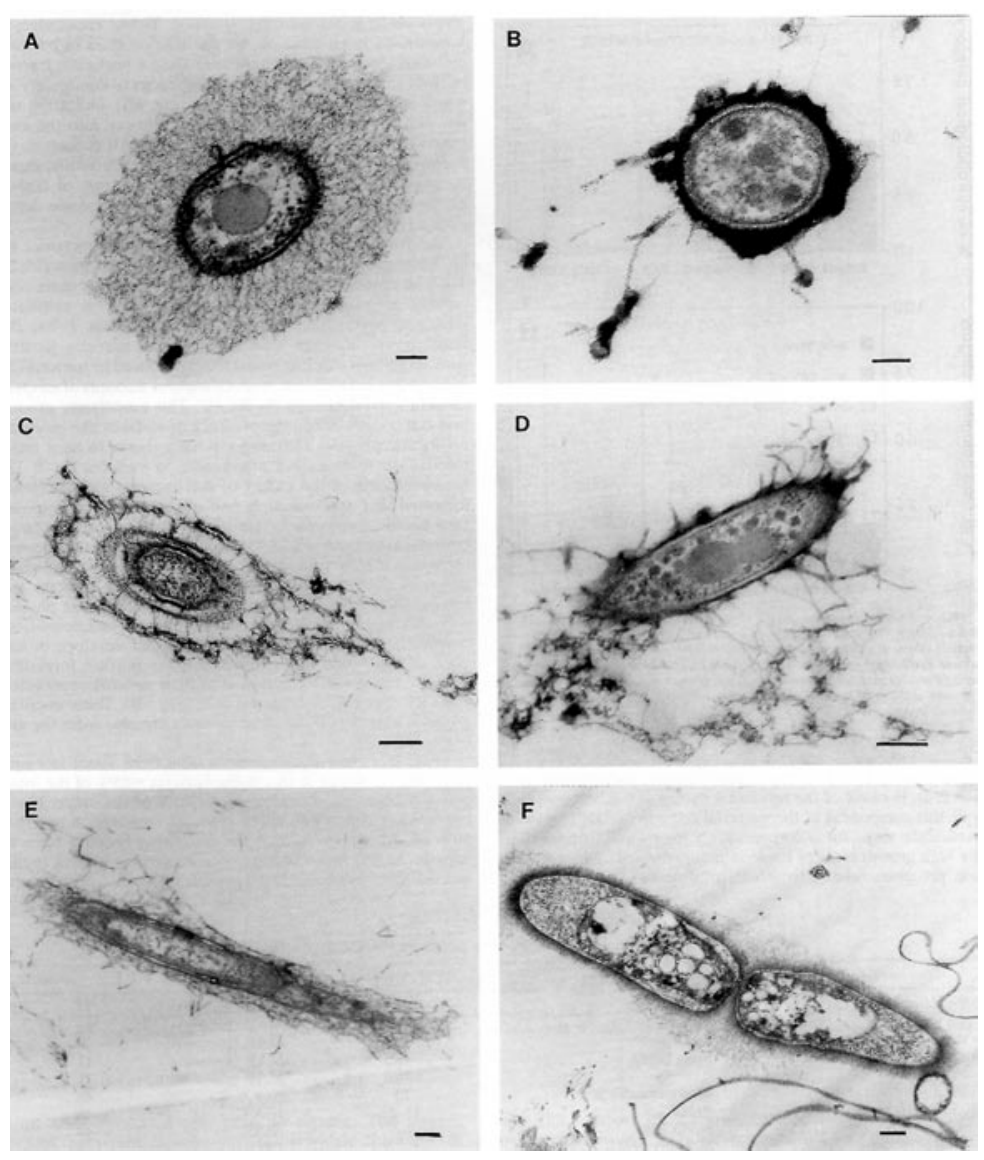

Figure 2. TEM images of the most common types of capsules found in free-living marine bacteria. Note that the morphology of the capsules varies considerably. $D$ and $\mathrm{F}$ (a dividing cell) were observed near marine snow particles. Scale bars: $A$ and $B-$ $100 \mathrm{~nm}, \mathrm{C}$ to $\mathrm{F}-200 \mathrm{~nm}$. TEM pictures adapted from Heissenberger et al. (1996) 
lism are independent of anabolism and proceed at maximal rates (Russell and Cook, 1995). Maintaining maximal rates of energy flow within a cell keeps cellular membranes energized and the active transport system functional. This "energized" physiological state is advantageous for cell growth, leaving cells poised to exploit transient but favorable environmental conditions associated with patchiness of available organic and inorganic nutrients (del Giorgio and Cole, 1998). Thus, while cells sacrifice thermodynamic efficiency, their BGE appears to be optimal to support maximal growth rates (Westernhoff et al., 1983).

\section{Factors That Can Affect BGE}

\section{Abiotic Factors}

Physical factors that hasten biochemical breakdown within a cell will affect the maintenance energy requirement and lower BGE. In a comprehensive review of BGE, Rivkin and Legendre (2001) suggest a significant inverse relationship between temperature and BGE, based on observations that the fraction of respired assimilated carbon is greater at lower latitudes compared to higher latitudes. Because there are major environmental gradients superimposed on this latitudinal range, it is possible that the pattern reported by Rivkin and Legendre (2001) may result from factors other than temperature. However, Apple et al. (2006) also observed a negative relationship between temperature and BGE in estuarine and coastal sites, and experimentally confirmed the temperature effect on BGE. The influence of temperature on bacterial carbon metabolism is complex, and not all reports agree with the patterns described above. Although trends appear to hold across large temperature ranges, the relationship is weak at any given site in which temperature range is $<10^{\circ} \mathrm{C}$. For example, a large systematic increase in BGE (i.e., $<10 \%$ to $>35 \%$ ) was observed throughout the course of a phytoplankton bloom in the Ross Sea, Antarctica, despite little change in temperature $\left(-2^{\circ} \mathrm{C}\right.$ to $+2^{\circ} \mathrm{C}$ ) (Carlson and Hansell, 2003). In the southern North Sea, Reinthaler and Herndl (2005) observed the opposite trend in which BGE increased from winter through spring as temperatures warmed. The rise in BGE observed in these studies suggests that other factors, such as DOM bioavailability during a phytoplankton bloom, had a greater effect relative to temperature.

Additionally, abiotic factors may affect bacterial energetic constraints. For example, ultraviolet irradiation, exposure to toxic substances, or osmotic shock may result in large increases in cell respiration associated with protection and repair, and consequent declines in BGE and growth (Koch, 1997). Although these effects have been difficult to document for marine bacterioplankton in situ, there is some evidence of large declines in BGE in freshwater to saltwater transition zones in estuaries (del Giorgio and Bouvier, 2002).

\section{Nutrient Limitation}

The stoichiometry of bacterioplankton is relatively constant (i.e., $\mathrm{C}: \mathrm{N}$ ratio

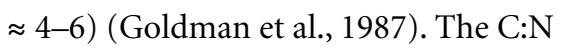
and C:P ratios of oceanic DOM range from 9-18 and 180-570, respectively (Benner, 2002). If the substrate supporting bacterial growth is relatively C-rich, one might expect to observe greater catabolism of DOC in order to balance elemental requirements of the cell. Studies of natural assemblages grown on media enriched with single $\mathrm{C}$ or $\mathrm{N}$ compounds generally support this trend (Goldman et al., 1987). However, in culture studies where multiple $\mathrm{C}$ or $\mathrm{N}$ sources were available, no trend between BGE and substrate stoichiometry was observed (Goldman and Dennett, 2000). In natural systems, no discernable trend is observed between BGE and DOM stoichiometry largely because the actual stoichiometric ratio of the available DOM is unknown. In addition, natural assemblages of prokaryotes likely use multiple sources of organic $\mathrm{C}, \mathrm{N}$, and $\mathrm{P}$ as well as inorganic $\mathrm{N}$ and $\mathrm{P}$, making understanding the relationship among substrate stoichiometry, BGE, and microbial growth extremely complex in natural systems (Vallino et al., 1996). Other studies demonstrate a more direct relationship between nutrient limitation and BGE. Tortell et al. (1999) show that under iron deficiency, electron-transport activities associated with respiration decrease, resulting in a significant reduction in BGE. Addition of inorganic phosphorus has been reported to increase microbial respiration in oligotrophic waters (Obernosterer et al., 2003).

\section{Lability (Availability) of DOM}

Not all microbes can break down all DOM (Floodgate, 1995). The oceanic DOM pool represents a continuum of biological lability, ranging from refractory material that turns over on time scales of centuries to millennia (Williams and Druffel, 1987; Bauer et al., 1992) to more available material turning over on time scales of minutes to days 
(Cherrier et al., 1996; Carlson, 2002).

The bulk DOM pool is often conceptually partitioned into broad pools of lability, increasing in concentration from a "labile," to a "semi-labile," to a "refractory" pool (see Carlson, 2002, and to maintain high electrochemical potential and support transport systems for other limiting nutrients.

Although LMW monomers are more easily taken up relative to polymeric material, not all LMW DOM is available

\title{
Although prokaryotic processes occur on
}

\author{
the spatial scale of nanometers, their \\ sheer numbers and the rates at which \\ they operate have major implications \\ on the scale of ecosystems.
}

citations therein). Bacteria are limited to transporting low molecular weight DOM (LMW DOM < 700 Da [dalton $=$ atomic mass unit]) via permeases (enzymes that transport other substances across cell membranes); thus, labile compounds such as dissolved free neutral sugars or dissolved free amino acids are assimilated easily by the cell's uptake mechanisms (Keil and Kirchman, 1999). However, efficient DOM uptake does not always equate to increased BGE. For example, in experiments where natural assemblages of oligotrophic bacterioplankton were amended with labile carbon in the form of glucose, Carlson et al. (2002) observed that as much as $85 \%$ of the glucose carbon was respired as $\mathrm{CO}_{2}$ within a few days. The rapid uptake and subsequent remineralization of this labile DOC resulted in only a small increase in cell production, suggesting that most of available DOC was utilized for uptake. Indeed, the greater majority of oceanic DOM is uncharacterized LMW material that is resistant to microbial attack (Benner, 2002). Amon and Benner $(1994,1996)$ propose the size-continuum model in which the high molecular weight DOM is more bioreactive and available to microbial utilization than the majority of the LMW DOM. However, enhanced bioavailability does not necessarily equate to enhanced BGE. Hydrolysis of large polymeric molecules and subsequent DOM uptake can be energetically costly and offset the nutritional advantage resulting in low BGE.

\section{Energetic Quality}

DOM quality can also refer to the biologically available energy from DOM oxidation. Growth efficiency and biomass production of organisms grown on a relatively oxidized substrate will be low even if the supply is high (del Giorgio and Cole, 1998, and citations therein). Bacteria consume a wide range of organic compounds simultaneously, and although the nature of the organic matter consumed in the oceans is not well known, there is evidence that very different pools are used. For example, Cherrier et al. (1999) demonstrated that at least a portion of the carbon used by oceanic bacteria is old ( $>500$ years), and thus probably differs in its energetic contents from recently fixed carbon. The relative importance of these different pools of DOM lability likely plays a major role in shaping oceanic BGE patterns.

Viral Activity

Phage infection can contribute up to $50 \%$ of bacterial mortality. Upon lytic infection, cells burst, spilling viruses and organic matter into their environment. As the viral-mediated DOM release is reincorporated into bacterioplankton, bacterial respiration increases by as much as 30\% (Fuhrman, 1999). Viral infection can also decrease the BGE of noninfected bacteria as a result of the increased energy demands associated with the degradation of polymeric organic nitrogen and phosphorus lysates (Middelboe et al., 1996).

\section{Bacterial Diversity}

Significant diversity of prokaryotic communities exists in oceanic systems. Vertical stratification of major prokaryotic groups between the oceanic euphotic and aphotic zones has been observed (Giovannoni et al., 1996; Karner et al., 2001; Moeseneder et al., 2001; Morris et al., 2002). The mechanisms responsible for spatial variability of specific prokaryotic groups or phylotypes over 
depth are not well understood. However, conceptual models provide compelling reasons to believe that the growth of specific heterotrophic microbial populations in planktonic ecosystems is linked to the composition and amount of DOM, as well as to the availability of inorganic nutrients.

Recent work in the North Sea indicates bacterial diversity can affect the BGE of the overall bacterial assemblage. Reinthaler et al. (2005) demonstrate that while the function of DOM remineralization to $\mathrm{CO}_{2}$ remains stable despite shifts in bacterial assemblage structure, the BGE is inversely related to bacterioplankton richness. This inverse relation between BGE and bacterial richness is largely mediated by bacterial production, which is generally more variable than respiration.

Interaction with Other

Metabolic Pathways

The recent discovery of the widespread occurrence of rhodopsin-like pigments in a variety of heterotrophic marine bacterial groups (see Kolber et al., this issue) suggests that nonphotosynthetic light utilization may be a common feature among marine heterotrophs in surface waters. These light-harvesting pathways, which result in energy fixation but are not necessarily coupled to carbon or oxygen dynamics, could play a significant role in shaping microbial bioegenergetics and thus influence the patterns in BGE. Gómez-Consarnau et al. (2007) demonstrate that proteorhodopsin-mediated photoheterotrophy significantly stimulates production of some marine Flavobacteria under oligotrophic conditions, thus supporting energy for respiration, maintenance, and active growth. However, other laboratory studies with the alpha-Proteobacteria Candidatus Pelagibacter ubique were unable to resolve differences in growth response between cultures incubated in the light versus the dark using nutrientenriched cultures (Giovannoni et al., 2005). Thus, light-mediated energy fixation could potentially increase the baseline BGE in the illuminated layers of the oceans under oligotrophic conditions by supplying additional energy to that derived from organic substrates, but the factors that control photoheterotrophy and its impact on the ocean carbon cycle are not yet fully understood.

\section{ECOSYSTEM}

\section{AND BIOGEOCHEMICAL}

\section{IMPLICATIONS}

As discussed above, the allocation of carbon and energy in marine bacteria depends on many factors, and it is difficult, if not impossible, to place the variation of $B G E$ as a function of a single variable. In general terms, however, BGE will tend to be low in situations of either insufficient supply of energy and nutrients, of inappropriate stoichiometry of resource supply, or under increased maintenance and repair requirements of the cells. These environmental factors may be summarized as the level of environmental “hostility” (Figure 3 ). This hostility may result from extreme lack of resources (i.e., organic matter or nutrients), overabundance of others (i.e., pollutants, allelopathic substances), physical or chemical stresses (i.e., salinity and temperature gradients, UV radiation, extreme $\mathrm{pH}$ gradients), or a combination of these. Regardless of its origin, increased overall environmental hostility will result in an increase in the proportion of the total flux of energy that is devoted to cell maintenance (EM). Associated with this increase in cell maintenance, it is expected that cell-specific respiration (SP) (standardized for differences in cell size among systems) should also increase to fuel the increased maintenance and repair. BGE will therefore decrease along this gradient of increasing environmental hostility. Figure 3 is hypothetical and the exact shapes of these curves are not known, but the ranges of BGE shown in the figure are realistic and are within what has been reported for marine systems, suggesting that marine bacterioplankton may experience a wide range in overall environmental hostility.

On the ecosystem level, microbial oceanographers are interested in how the hostility of the marine environment affects microbial energy partitioning and respiration and how the integration of all these individual cell processes affects the magnitude and efficiency by which organic matter flows through heterotrophic bacterioplankton. In practice, researchers have taken various approaches to determine the magnitude of organic matter flux through the oceanic bacterial component, including measurements of growth, biomass production, respiration, or a combination of the latter.

Indirect Estimates of Bacterial Carbon Demand

Estimates of BP via uptake of radioactive tracers are by far the most common measurements of bacterial metabolism and are routinely carried out in marine studies. There is thus a wealth of data 


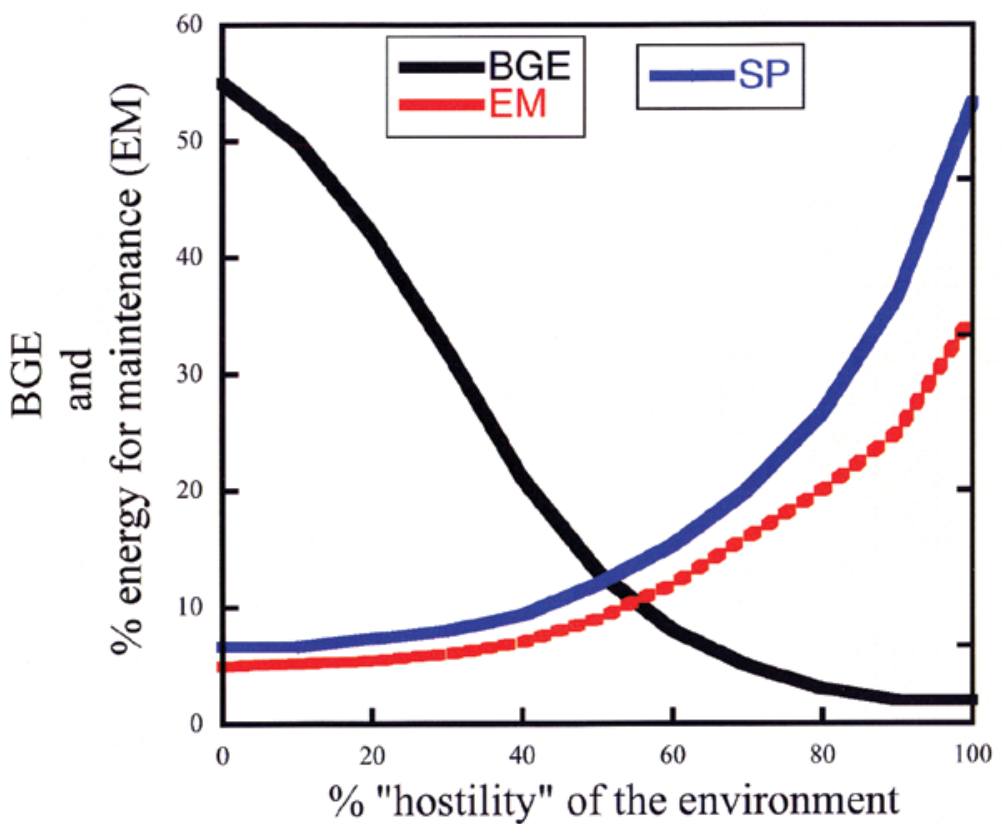

Figure 3. Conceptual diagram demonstrating the relationship between environmental stressors or environmental "hostility" and the partitioning of energy within a bacterial cell, the resulting bacterial growth efficiency (BGE), and cell specific respiration. As environmental hostility increases, more energy is partitioned into maintenance energy (EM). Thus, bacterial growth efficiency decreases and cell-specific respiration (SP) increases. Some combination of both physical (temperature, $\mathrm{pH}$, salinity) and chemical (toxins, substrate availability) factors contribute to environmental hostility

from a wide range of oceanic regions (Ducklow and Carlson, 1992; Ducklow, 1999). Cole et al. (1988) first reported that, in the euphotic zone, BP was positively and significantly correlated to primary production (PP) across a wide range of aquatic ecosystems, and concluded that net BP averaged about $30 \%$ of PP. In similar analyses of seven oceanic sites, Ducklow (1999) concluded that BP was $<20 \%$ of PP.

Although the magnitude of net BP appears modest compared to PP, one must consider the efficiency by which bacterioplankton convert DOC into bacterial biomass. The flux of carbon needed to support a given estimate of BP is referred to as bacterial carbon demand (BCD). It is possible to derive BCD, and thus total carbon consumption (BR plus $\mathrm{BP})$, by combining measurements of BP with estimates of BGE, such that,

$\mathrm{BCD}=\mathrm{BP} / \mathrm{BGE}$

One of the main findings in the past decade is that marine BGE is both far more variable and much lower than what was traditionally assumed in modas hypothesized by Jahnke and Craven (1995) over a decade ago. For example, there is growing evidence from field experiments that BGE generally increases along trophic gradients, from $<10 \%$ in oligotrophic oceanic water to $>20 \%$ in the most productive environments (Ducklow and Carlson, 1992; del Giorgio and Cole, 1998; Biddanda et al., 2001). els of bacterial carbon consumption,
Further, a recent quantitative review of published marine BGE measurements concludes that the median BGE for the surface open ocean is $8 \%$ and for the coastal ocean is $16 \%$ (Robinson, in press). Within the ocean interior, estimates of BGE are even lower. Carlson et al. (2004) estimate BGE to be $8 \pm 4 \%$ for bacterioplankton in the upper mesopelagic zone after convective overturn, and Reinthaler et al. (2006) find BGE to be $<2 \%$ in the bathypelagic zone deeper than $1000 \mathrm{~m}$.

The finding that BGE is generally low but highly variable has both conceptual and practical consequences. From a conceptual point of view, these field observations support the hypothesis that, in dynamic environments under condition of low nutrient supply, microbes have evolved versatile metabolic machinery to take advantage of multiple nutrient, carbon, and energy sources. By increasing the capacity of enzymes in the uptake/ assimilation systems, a larger percentage of energy is funneled into maintenance processes to safeguard metabolic flexibility at the cost of energetic efficiency (Teixeira-de-Mattos and Neijssel, 1997). From a practical point of view, a lower BGE implies a relatively larger flux of carbon to support an observed BP; thus, $\mathrm{BCD}$ can be a greater percentage of $\mathrm{PP}$ in low-productivity systems.

Interestingly, this approach generally leads to estimates of BCD in the open-ocean euphotic zone that are often similar to or greater than the estimates of local PP (Ducklow, 1999; del Giorgio et al., 1997) when PP values are low (Figure 4). Figure 4 shows integrated euphotic zone BCD estimates in relation to integrated PP. These data dem- 


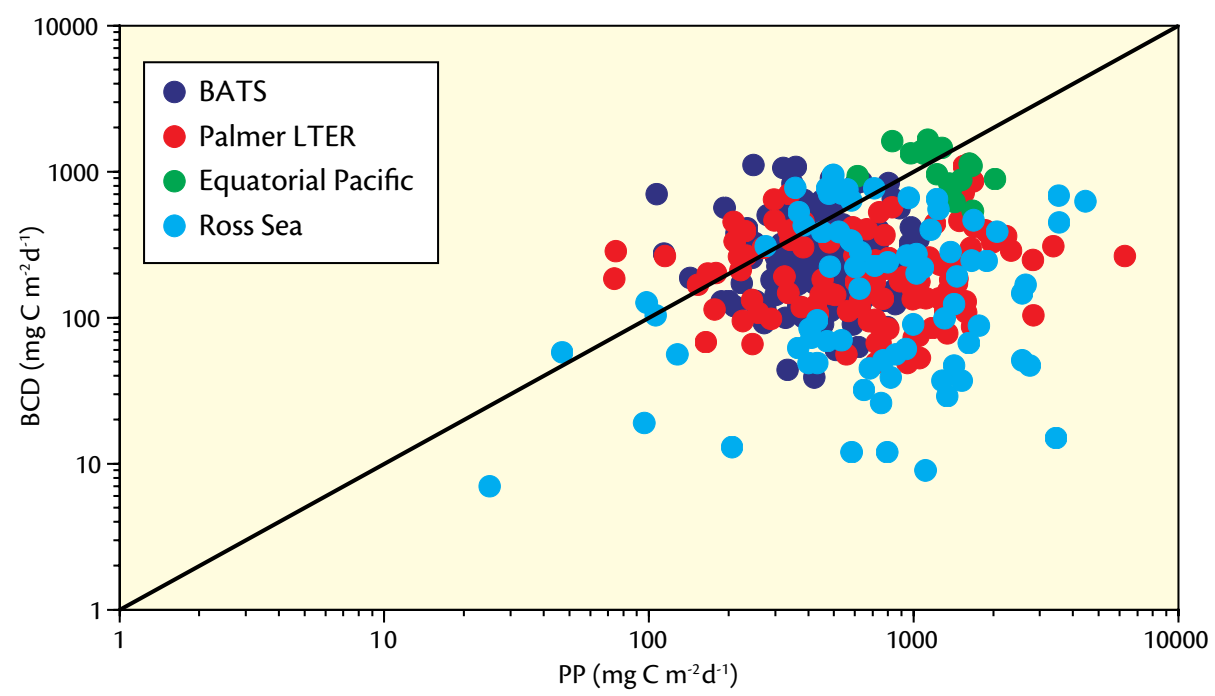

Figure 4. Relationship between integrated bacterial carbon demand (BCD) and primary production (PP) within the euphotic zone of representative ocean sites. All data are derived from paired measurements of bacterial production and PP integrated within the euphotic zone from each study site. A common bacterial growth energy of 0.1 was used to estimate $B C D$. The black line represents the 1:1 line. Data points that lie above this line indicate that bacterial carbon demand was greater than local primary production at the time of sample collection. The Bermuda Atlantic Time-series Study (BATS) data represent monthly values from 1991-2003 ( $n=155$; see Steinberg et al., 2001 for details; data available at http://bats. bbsr.edu/). Paired BP and PP from the Equatorial Pacific $(n=16)$ and Ross Sea, Antarctica, $(n=77)$ were calculated according to Ducklow (1999) (data available at http://usjgofs.whoi. edu/jg/dir/jgofs/). All data from the Palmer Peninsula, Antarctica, $(n=112)$ provided by H. Ducklow and the Palmer LTER program.

onstrate that when PP is $>1 \mathrm{~g} \mathrm{~m}^{-2} \mathrm{~d}^{-1}$, $\mathrm{BCD}$ was significantly less than local PP. However, when PP is $<1 \mathrm{~g} \mathrm{~m}^{-2} \mathrm{~d}^{-1}$, BCD can be similar to or greater than local estimates of PP, indicating an apparent mismatch between what bacteria consume and what appears to be available for consumption.

Waters deeper than $200 \mathrm{~m}$ comprise $\approx 75 \%$ of the volume of the global ocean, yet little is known about the microbial processes that persist at depth. Recent studies demonstrate enhanced prokaryotic activity and BCD within the ocean's mesopelagic and bathypelagic zones (Arístegui et al., 2005; Reinthaler et al., 2006). Reinthaler et al. (2006) compare BCD with particulate organic carbon
(POC) flux into the interior. They find that the gap between BCD and POC supply lead to a deficiency of as much as an order of magnitude at depths greater than $1000 \mathrm{~m}$.

The apparent imbalance that results from combining current measurements of BP and BGE and comparing the resulting carbon consumption with primary production or POC flux (in the case of deeper waters) may be either a real feature of oceanic systems or the result of current uncertainties in the metabolic measurements. Routine measurements of BP via the thymidine or leucine uptake methods are only a proxy for bacterial production; accurate estimates are confounded by variability in the conversion factors needed to estimate cell or carbon production (Ducklow and Carlson, 1992; Ducklow, 2000). Measurements of BGE also have their own set of shortcomings due to technical difficulties (Robinson and Williams, 2005). Thus, it is clear that our understanding of BGE and, consequently, estimates of BCD in the oceans is still very uncertain, and that direct measurements of BR and total community respiration are required to better constrain the flux of energy and organic matter in oceanic systems.

\section{Direct Measurements of Bacterial Respiration}

Bacterial respiration still represents a major technical challenge and in spite of its obvious importance, there is a paucity of direct BR measurements. The available oceanic BR data set is extremely modest, especially compared to existing measurements of other carbon fluxes, such as bacterial and algal production. A recent synthesis concluded that there are fewer than 500 individual measurements for the global euphotic ocean, which result in a median (mean \pm standard deviation) BR of $0.5 \mathrm{mmol} \mathrm{C} \mathrm{m}^{-3} \mathrm{~d}^{-1}$ $\left(1.3 \pm 2.3 \mathrm{mmol} \mathrm{C} \mathrm{m}^{-3} \mathrm{~d}^{-1}, \mathrm{n}=105\right)$ and $3.1 \mathrm{mmol} \mathrm{C} \mathrm{m}^{-3} \mathrm{~d}^{-1}(10.5 \pm 20.9 \mathrm{mmol}$ $\mathrm{C} \mathrm{m}^{-3} \mathrm{~d}^{-1}, \mathrm{n}=332$ ) for the open ocean and coastal regions, respectively (Robinson in press). These rates are very significant relative to other major carbon fluxes, such as primary production and carbon export, as we discuss below.

Despite the modest size of the available database, these direct measurements of BR tend to support the patterns obtained by combining BP and BGE: bacterial carbon consumption is high, 
particularly in olgotrophic systems, and often exceeds local estimates of primary production. The existing data further suggest that bacteria are the largest contributors to community respiration in the oceanic system. Within the euphotic zone of marine systems, BR represents a large fraction ( $\approx 50 \%$ to $>90 \%)$ of community respiration (Sherr and Sherr, 1996; Biddanda et al., 2001; Rivkin and Legendre, 2001; Robinson and Williams, 2005).

Other studies using estimates of respiration from changes in $\mathrm{O}_{2}$ in bottle experiments also report that portions of the surface oligotrophic open ocean appear to be net heterotrophic (Duarte and Agusti, 1998). But, what about metabolic balance in the open sea? The apparent discrepancy is interesting and controversial (Geider, 1997; Williams, 1998; Williams and Bowers, 1999; Goldman and Dennett, 2000), but perhaps provides insight to better interpret $C$ and energy flow in the open sea. We explore recent findings and evaluations below.

\section{METABOLIC BALANCE}

Current evidence suggests that the total carbon consumption by heterotrophic bacteria represents one of the largest components of the marine biological carbon budget, and that much of this carbon is respired by bacteria. Respiration, on the ecosystem level, represents the largest sink of organic matter in the biosphere and accounts for the total amount of organic matter oxidized, oxygen consumed, and $\mathrm{CO}_{2}$ produced. On a global scale, respiration must be balanced by the input of organic matter via primary production. On the local scale, this relationship can become more complicated and potentially weakened due to temporal uncoupling between respiration and primary production (Billen, 1990) or large transport of organic matter between ocean sectors (Hansell et al., 2004), and can result in an unbalance between respiration and local production sources. Better understanding of oceanic respiration will ultimately help oceanographers assess the magnitude of organic carbon input and help interpret measurements of primary production (Williams et al., 2004).

Neither bacterial nor community respiration within any ecosystem can exceed the supply of organic carbon. In circumstances where bacteria or the net community respire more than is produced by local photosynthesis (net heterotrophy), there must be an allochthonous (outside the system) input of organic matter. Because all ecosystems are open to exchange of organic matter, local environments may not be in metabolic balance. It is easy to envision how external input of organic matter from otrophy is counter intuitive and controversial (Williams et al., 2004).

To test the hypothesis of net heterotrophy within the euphotic zone of the oligotrophic gyres and address some criticism of temporal- and spatialscale problems from previous studies, Williams et al. (2004) designed a yearlong investigation of metabolic balance at the Hawaiian Ocean Time-series (HOT) site (Station ALOHA) in the oligotrophic North Pacific. They directly measured respiration and primary production by monitoring $\mathrm{O}_{2}$ changes in light/dark bottles incubated for 24 hours in vitro over six depths within the euphotic zone. Their integrated results indicate a metabolic deficit equivalent to $40 \%$ of measured primary production.

\section{Discrepancy with \\ Geochemical Estimates}

Evidence from several independent geochemical measures all point to net organic carbon production even in oligotrophic sites (Doney, 1997). For exam-

\section{Existing data...suggest that bacteria are the largest contributors to community respiration in the oceanic system.}

terrestrial runoff or advected organic matter from coastal blooms can subsidize respiration in estuarine and coastal systems. But for open-ocean systems like oligotrophic gyres that are physically isolated from allochthonous inputs of labile organic matter, the notion of net heter- ple, geochemical measurements at the two most intensively studied oligotrophic ocean sites at the Bermuda Atlantic Time-series Study (BATS) and HOT indicate annual patterns of $\mathrm{O}_{2}$ supersaturation in the euphotic zone (Steinberg et al., 2001; Karl et al., 2003), $\mathrm{O}_{2}$ efflux to 
the atmosphere (Emerson et al., 1997), net export of sinking organic particles from the surface waters (Karl et al., 1996; Steinberg et al., 2001), vertical export of DOC from the surface $100 \mathrm{~m}$ (Carlson et al., 1994), and long-term accumulation of DOM in the surface waters (Church et al., 2002). All of these independent observations require net organic carbon production to reconcile the data.

How Do We Explain the Metabolic Imbalance of Aquatic Ecosystems Indicated from These Approaches?

Granted, there are errors associated with the various approaches used to estimate community respiration, including in vitro $\mathrm{O}_{2}$ rate measurements or microbial respiration from $\mathrm{BGE}$ and $\mathrm{BP}$ (Robinson and Williams, 2005). Nonetheless, these data are still valuable and provide significant insight to our interpretation of metabolic balance. In their 2005 paper, del Giorgio and Williams state, "In reality there is essentially no imbalance, because aquatic ecosystems consume and respire all but a small amount of organic matter available. The apparent imbalances are artifacts that result from our largely insufficient understanding of the magnitude and regulation of total organic matter flux in aquatic ecosystems." Perhaps these apparent deficits tell us something about the approach we use to assess carbon and energy flow in oceans and its interpretation.

Geochemical in situ observations provide better spatial and temporal averaging compared to in vivo incubation approaches and are considered to have greater accuracy for estimating net organic carbon production (Williams et al., 2004). Accepting the geochemi- cal estimates as evidence of net organic matter production in the euphotic zone, Williams et al. (2004) explore alternative possibilities to explain the discrepancy. Rates of respiration are relatively constant compared to the large degree of primary productivity observed in aquatic ecosystems (del Giorgio and Williams, 2005). Part of this constancy is due to the fact that community respiration integrates all components of the food web and the various organic pools each component utilizes. In contrast, autotrophic production is more episodic and can become temporally decoupled from respiration (Karl et al., 2003). These pulses of energy and carbon from episodic events will be dampened as they flow through the heterotrophic component of the food web, thus yielding a more constant respiration signal. As a result, if the system is undersampled through time, the production term would be underestimated relative to consumption, yielding an apparent metabolic deficit (Karl et al., 2003; Williams et al., 2004).

Currently, the oceanographic benchmark for assessing the magnitude of energy and carbon that flows through an oceanic ecosystem is set by measurements of primary production. However, mass balance and inverse modeling approaches suggest that rates of organic matter production may be underestimated by a factor of two or more for ecosystems like the subtropical North Pacific gyre (Williams et al., 2004) or the global ocean (Robinson and Williams, 2005). Respiration is equal to the source of organic input and integrates over greater temporal scales; thus, in an undersampled system, it has the potential to be a more accurate measure of integrated net organic production than photosynthesis (Williams et al., 2004; del Giorgio and Williams, 2005). Because of its great integrating properties, microbial oceanographers should include more regular measurements of respiration in future studies to better constrain the magnitude of energy flow within the oceans, and to better understand the potential mechanisms that control it. Bacterioplankton are responsible for a large fraction of oceanic respiration, and therefore a better understanding of the controls of bacterial carbon consumption, and of the partition of this carbon between anabolic and catabolic pathways, will help to better understand global ocean respiration.

\section{ACKNOWLEDGEMENTS}

We would like to thank H. Ducklow for contributing unpublished data from the Palmer LTER program and for discussions that helped improve this manuscript. This review was supported by grants from the U.S. National Science Foundation.

\section{REFERENCES}

Amon, R.M.W., and R. Benner. 1994. Rapid cycling of high-molecular-weight dissolved organic matter in the ocean. Nature 369:549-552.

Amon, R.M.W., and R. Benner. 1996. Bacterial utilization of different size classes of dissolved organic matter. Limnology and Oceanography 41(1):41-51.

Apple, J., P.A. del Giorgio, and M. Kemp. 2006. The temperature-dependence of bacterioplankton carbon metabolism. Aquatic Microbial Ecology 43:243-254.

Arìstegui, J., S. Agustì, J.J. Middelburg, and C.M. Duarte. 2005. Respiration in the mesopelagic and bathypelagic zones of the ocean. Pp. 181205, in Respiration in Aquatic Ecosystems. P.A. del Giorgio and P.J. leB. Williams, eds, Oxford University Press.

Azam, F. 1998. Microbial control of oceanic carbon flux: The plot thickens. Science 280:694-696. 
Azam, F., T. Fenchel, J.G. Field, J.S. Gray, L.A. Meyer-Reil, and F. Thingstad. 1983. The ecological role of water-column microbes in the sea. Marine Ecology Progress Series 10:257-263.

Bauer, J.E., P.M. Williams. and E.R.M. Druffel. 1992. ${ }^{14} \mathrm{C}$ activity of dissolved organic carbon fractions in the north-central Pacific and Sargasso Sea. Nature 357:667-670.

Benner, R.H. 2002. Chemical composition and reactivity. Pp. 59-90 in Biogeochemistry of Marine Dissolved Organic Matter. D.A. Hansell and C.A. Carlson, eds, Academic Press, San Diego, California.

Biddanda, B., M. Ogdahl, and J. Cotner. 2001. Dominance of bacterial metabolism in oligotrophic relative to eutrophic waters. Limnology and Oceanography 46(3):730-739.

Billen, G. 1990. Delayed development of bacterioplankton with respect to phytoplankton: A clue to understanding their trophic relationship. Ergebnisse der Limnologie 34:191-201.

Brophy, J.E., and D.J. Carlson. 1989. Production of biologically refractory dissolved organic carbon by natural seawater microbial populations. Deep-Sea Research 36(4):497-507.

Carlson, C.A. 2002. Production and Removal Processes. Pp. 91-151 in Biogeochemistry of Marine Dissolved Organic Matter. D.A. Hansell and C.A. Carlson, eds, Academic Press, San Diego, CA.

Carlson, C.A., H.W. Ducklow, and A.F. Michaels. 1994. Annual flux of dissolved organic carbon from the euphotic zone in the Northwestern Sargasso Sea. Nature 371:405-408.

Carlson, C.A., and D.A. Hansell. 2003. The Contribution of dissolved organic carbon and nitrogen to biogeochemistry of the Ross Sea. Pp. 123-142 in Biogeochemical Cycles in the Ross Sea. Antarctic Research Series Volume 78, G. DiTullio and R. Dunbar, eds, American Geophysical Union Press, Washington, D.C.

Carlson, C.A., S.J. Giovannoni, D.A. Hansell, S.J. Goldberg, R. Parsons, and K. Vergin. 2004. Interactions between DOC, microbial processes, and community structure in the mesopelagic zone of the northwestern Sargasso Sea. Limnology and Oceanography 49:1,073-1,083.

Cherrier, J., J.E. Bauer, and E.R.M. Druffel. 1996.

Utilization and turnover of labile dissolved organic matter by bacterial heterotrophs in eastern North Pacific surface waters. Marine Ecology Progress Series 139:267-279.

Cherrier, J., J.E. Bauer, E.R.M. Druffel, R.B. Coffin, and J.P. Chanton. 1999. Radiocarbon in marine bacteria: Evidence for the ages of assimilated carbon. Limnology and Oceanography 44:730-736.

Cole, J.J., S. Finlay, and M.L. Pace. 1988. Bacterial production in fresh and saltwater ecosystems: A cross-system overview. Marine Ecology Progress Series 43:1-10.

Church, M.J., H.W. Ducklow, and D.M. Karl. 2002. Multi-year increases in dissolved organic matter inventories at Station ALOHA in the North Pacific Subtropical Gyre. Limnology and Oceanography 47(1):1-10.

del Giorgio, P.A., and T.C. Bouvier. 2002. Linking the physiologic and phylogenetic successions in free-living bacterial communities along an estuarine gradient. Limnology and Oceanography 47:471-486.

del Giorgio, P., and J.J. Cole. 1998. Bacterial growth efficiency in natural aquatic systems. Annual Review of Ecological Systems 29:503-541.

del Giorgio, P.A., J.J. Cole, and A. Cibleris. 1997. Respiration rates in bacteria exceed phytoplankton production in unproductive aquatic systems. Nature 385:148-151.

del Giorgio, P.A., and P.J.leB. Williams. 2005. The global significance of respiration in aquatic ecosystems: From single cells to the biosphere. Pp. 267-303 in Respiration in Aquatic Ecosystems. P.A. del Giorgio and P.J.leB. Williams. eds, Oxford University Press, New York.

DeLong, E.F., C.M. Preston, T. Mincer, V. Rich, S.J. Hallam, N.U. Frigaard, A. Martinez, M.B. Sullivan, R. Edwards, B.R. Brito, and others. 2006. Community genomics among stratified microbial assemblages in the ocean's interior. Science 311(5760):496-503.

Doney, S.C. 1997. The ocean's productive deserts. Nature 389:1,997.

Duarte, C.M., and S. Agusti. 1998. The $\mathrm{CO}_{2}$ balance of unproductive aquatic ecosystems. Science 281(5374):234-236.

Ducklow, H.W. 1999. The bacterial component of the oceanic euphotic zone. FEMS Microbial Ecology 30:1-10.

Ducklow, H. 2000. Bacterial production and biomass in the ocean. Pp. 85-120 in Microbial Ecology of the Oceans. D.L. Kirchman, ed., Wiley-Liss, Inc., New York.

Ducklow, H.W., and C.A. Carlson. 1992. Oceanic bacterial production. Pp. 113-181 in Advances in Microbial Ecology, Volume 12. K.C. Marshall, ed., Plenum Press, New York.

Ducklow, H.W., D.A. Purdie, P.J.leB. Williams, and J.M. Davies. 1986. Bacterioplankton: A sink for carbon in a coastal marine plankton community. Science 232:865-867.

Emerson, S., P. Quay, D.M. Karl, C. Winn, L. Tupas, and M. Landry. 1997. Experimental determination of the organic carbon flux from openocean surface waters. Nature 389:951-954.

Floodgate, G.D. 1995. Some environmental aspects of hydrocarbon bacteriology. Aquatic Microbial
Ecology 9:3-11.

Fuhrman, J.A. 1999. Marine viruses and their biogeochemical and ecological effects. Nature 399:541-548.

Geider, R.J. 1997. Photosynthesis or planktonic respiration. Nature 388(6638):132.

Giovannoni, S.J., L. Bibbs, J.C. Cho, M.D. Stapels, R. Desiderio, K.L. Vergin, M.S. Rappé, S. Laney, L.J. Wilhelm, H.J. Tripp, and others. 2005. Proteorhodopsin in the ubiquitous marine bacterium SAR11. Nature 438(7064):82-85.

Giovannoni, S.J., M.S. Rappé, K. Vergin, and N. Adair. 1996. 16S rRNA genes reveal stratified open ocean bacterioplankton populations related to the green non-sulfur bacteria phylum. Proceedings of the National Academy of Sciences of the United States of America 93:7,979-7,984.

Giovannoni, S.J., and U. Stingl. 2005. Molecular diversity and ecology of microbial plankton. Nature 437(7057):343-348.

Goldman, J., D.A. Caron, and M.R. Dennett. 1987. Regulation of gross growth efficiency and ammonium regeneration in bacteria by substrate C:N ratio. Limnology and Oceanography 32(6):1,239-1,252.

Goldman, J.C., and M.R. Dennett. 2000. Growth of marine bacteria in batch and continuous culture under carbon and nitrogen limitation. Limnology and Oceanography 45(4):789-800.

Gómez-Consarnau, L., J.M. González, M. CollLladó, P. Gourdon, T. Pascher, R. Neutze, C. Pedós-Alió, and J. Pinhassi. 2007. Light stimulates growth of proteorhodopsin-containing marine Flavobacteria. Nature 445:210-213.

Hansell, D.A., H.W. Ducklow, A.M. Macdonald, and M. O'Neil Baringer. 2004. Metabolic poise in the North Atlantic Ocean diagnosed from organic matter transports. Limnology and Oceanography 49(4):1,084-1,094.

Heissenberger, A., and G.H. Herndl. 1994. Formation of high molecular weight material by free-living marine bacteria. Marine Ecology Progress Series 111:129.

Heissenberger, A., G.G. Leppard, and G.J. Herndl. 1996. Relationship between the intracellular integrity and the morphology of the capsular envelope in attached and free-living marine bacteria. Applied and Environmental Microbiology 62:4,521-4,528.

Hoehler, T.M. 2004. Biological energy requirements as quantitative boundary conditions for life in the subsurface. Geobiology 2:205-215.

Jahnke, R.A., and D.B. Craven. 1995. Quantifying the role of heterotrophic bacteria in the carbon cycle: A need for respiration measurements. Limnology and Oceanography 40:436-441.

Jones, C.W. 1983. Bacterial Respiration and Photosynthesis. American Society for 
Microbiology, Washington, D.C.

Karl, D.M., J.R. Christian, J.E. Dore, D.V. Hebel, R.M. Letelier, L.M. Tupas, and C.D. Winn. 1996. Seasonal and interannual variability in primary production and particle flux at Station ALOHA. Deep-Sea Research Part II 43:539-568.

Karl, D.M., E.A. Laws, P. Morris, P.J.leB Williams, and S. Emerson. 2003. Metabolic balance of the open sea. Nature 426:32.

Karner, M.B., E.F. DeLong, and D.M. Karl. 2001. Archaeal dominance in the mesopelagic zone. Nature 409:507-510.

Kawasaki, N., and R. Benner. 2006. Bacterial release of dissolved organic matter during cell growth and decline: Molecular origin and composition. Limnology and Oceanography 51(5):2,170-2,180.

Keil, R.G., and D.L. Kirchman. 1999. Utilization of dissolved protein and amino acids in the northern Sargasso Sea. Aquatic Microbial Ecology 18:293-300.

King, G.M. 2005. Ecophysiology of microbial respiration. Pp. 18-35 in Respiration in Aquatic Ecosystems, Volume 18. P.A. del Giorgio and P.J.leB. Williams, eds, Oxford University Press, New York.

Koch, A.L. 1997. Microbial physiology and ecology of slow growth. Microbiology and Molecular Biology Reviews 61:1,092-2,172.

Liu, Y. 1998. Energy uncoupling in microbial growth under substrate-sufficient conditions. Applied Microbiology and Biotechnology 49:500-505

McCarthy, M.D., J.I. Hedges, and R. Benner. 1998. Major bacterial contribution to marine dissolved organic nitrogen. Science 281:231-234.

Middelboe, M., N.O.G. Jørgensen, and N. Kroer. 1996. Effects of viruses on nutrient turnover and growth efficiency of noninfected marine bacterioplankton. Applied and Environmental Microbiology 62(6):1,991-1,997.

Moeseneder, M.M., C. Winter, and G.J. Herndl. 2001. Horizontal and vertical complexity of attached and free-living bacteria of the Eastern Mediterranean Sea, determined by $16 \mathrm{~S}$ rDNA and 16S rRNA fingerprints. Limnology and Oceanography 46(1):95-107.

Morris, R.M., S.A. Connon, M.S. Rappé, K.L. Vergin, W.A. Siebold, C.A. Carlson, and S.J. Giovannoni. 2002. High cellular abundance of the SAR11 bacterioplankton clade in seawater. Nature 420:806-809.

Obernosterer, I., N. Kawasaki, and R. Benner. 2003. P-limitation of respiration in the Sargasso Sea and uncoupling of bacteria from P-regeneration in size-fractionation experiments. Aquatic Microbial Ecology 32:229-237.

Ogawa, H., Y. Amagai, I. Koike, K. Kaiser, and R.
Benner. 2001. Production of refractory dissolved organic matter by bacteria. Science 292:917-920.

Pomeroy, L.R. 1974. The ocean's food web, a changing paradigm. BioScience 24:499-504.

Reinthaler, T., and G.J. Herndl. 2005. Seasonal dynamics of bacterial growth efficiencies in relation to phytoplankton in the southern North Sea. Aquatic Microbial Ecology 39(1):7-16.

Reinthaler, T., H. van Aken, C. Veth, J. Aristegui, C. Robinson, P.J.leB. Williams, P. Lebaron, and G.J. Herndl. 2006. Prokaryotic respiration and production in the meso- and bathypelagic realm of the eastern and western North Atlantic basin. Limnology and Oceanography 51(3):1,262-1,273

Reinthaler, T., C. Winter, and G.J. Herndl. 2005. Relationship between bacterioplankton richness, respiration, and production in the southern North Sea. Applied and Environmental Microbiology 71(5):2,260-2,266.

Rivkin, R.B., and L. Legendre. 2001. Biogenic carbon cycling in the upper ocean: Effects of microbial respiration. Science 291:2,398-2,400.

Robinson, C. In press. Heterotrophic bacterial respiration. In Marine Microbial Ecology, $2^{\text {nd }}$ Edition. D. Kirchman, ed., Plenum Press, New York.

Robinson, C., and P.J.leB. Williams. 2005. Respiration and its measurement in surface marine waters. Pp. 147-180 in Respiration in Aquatic Ecosystems. P.A. del Giorgio and P.J.leB. Williams, eds, Oxford University Press, New York.

Russell, J.B., and G.M. Cook. 1995. Energetics of bacterial growth: Balance of anabolic and catabolic reactions. Microbiology Reviews 59:48-62.

Sherr, E.B., and B.E. Sherr. 1996. Temporal offset in oceanic production and respiration processes implied by seasonal changes in atmospheric oxygen: The role of heterotrophic microbes. Aquatic Microbial Ecology 11:91-100.

Steinberg, D.K., C.A. Carlson, N.R. Bates, R.J. Johnson, A.F. Michaels, and A.H. Knap. 2001. Overview of the U.S. JGOFS Bermuda Atlantic Time-series Study (BATS): A decade-scale look at ocean biology and biogeochemistry. Deep-Sea Research Part II 48:1,405-1,447.

Tanoue, E., S. Nishiyama, M. Kamo, and A. Tsugita. 1995. Bacterial membranes: Possible source of a major dissolved protein in seawater. Geochimica et Cosmochimica Acta 59(12):2,643-2,648.

Teixeira-de-Mattos, M.J., and O.M. Neijssel. 1997. Bioenergetic consequences of microbial adaptation to low-nutrient environments. Journal of Biotechnology 59:117-126.

Tortell, P.D., M.T. Maldonado, J. Granger, and N.M. Price. 1999. Marine bacteria and biogeo- chemical cycling of iron in the oceans. FEMS Microbial Ecology 29:1-11.

Vallino, J.J., C.S. Hopkinson, and J.E. Hobbie. 1996. Modeling bacterial utilization of dissolved organic matter: Optimization replaces Monod growth kinetics. Limnology and Oceanography 41(8):1,591-1,609.

Venter, J.C., K. Remington, J.F. Heidelberg, A.L. Halpern, D. Rusch, J.A. Eisen, D. Wu, I. Paulsen, K.W. Nelson, W. Nelson, and others. 2004. Environmental genome shotgun sequencing of the Sargasso Sea. Science 304:66-72.

Westernhoff, H.V., K.J. Hellingwerf, and K. Van Dam. 1983. Thermodynamic efficiency of microbial growth is low but optimal for maximal growth rate. Proceedings of the National Academy of Sciences of the United States of America 80:305-309.

Whitman, W.B., D.C. Coleman, and W.J. Wiebe. 1998. Prokaryotes: The unseen majority. Proceedings of the National Academy of Sciences of the United States of America 95:6,578-6,583.

Williams, P.J.leB. 1998. The balance of plankton respiration and photosynthesis in the open oceans. Nature 394(6688):55-57.

Williams, P.J.leB., and D.G. Bowers. 1999. Regional carbon imbalances in the ocean. Science 284:173-174.

Williams, P.J.leB., and P.A. del Giorgio. 2005. Respiration in aquatic ecosystems: History and background. Pp. 1-17 in Respiration in Aquatic Ecosystems. P.A. del Giorgio and P.J.leB. Williams, eds, Oxford University Press, New York.

Williams, P.J.leB., P.J. Morris, and D.M. Karl. 2004. Net community production and metabolic balance at the oligotrophic ocean site, station ALOHA. Deep-Sea Research Part I 51:1,563-1,578.

Williams, P.M., and E.R.M. Druffel. 1987. Radiocarbon in dissolved organic matter in the central North Pacific Ocean. Nature 330:246-248. 